\section{Role of novel and rare nucleotide substitutions of the $\beta$-globin gene}

\author{
Margherita Vinciguerra, Monica Cannata, \\ Filippo Cassarà, Pina Lo Gioco, \\ Filippo Leto, Cristina Passarello, \\ Antonino Giambona \\ Laboratory for Molecular Prenatal \\ Diagnosis of Hemoglobinopathies, \\ Department of Haematology for rare \\ diseases of blood and blood-forming \\ organs, Villa Sofia-Cervello Hospital, \\ Palermo, Italy
}

\section{Abstract}

The Laboratory for Molecular Prenatal Diagnosis of Hemoglobinopathies at the Villa Sofia-Cervello Hospital in Palermo, Italy, carries out an intensive screening program aimed at identifying the healthy carriers of thalassemia and, consequently, the couples at risk of bearing an affected fetus. The diagnostic process is basically divided into two phases: i) hematologic and hemoglobin data; ii) molecular analysis of globin genes and, when possible, a genetic study of the family. Since 2003, we have been performing DNA sequence analysis on those cases in which classical molecular methods failed to give a complete diagnostic response, particularly in phenotypes with borderline values of $\mathrm{HbA}_{2}$ with mild or absent microcytosis. During ten years of screening activities (from 2003 to 2012), twenty-seven unknown or rare nucleotide changes of the $\beta$-globin gene have been identified; hematologic and hemoglobin data have been carefully evaluated and, wherever possible, we have conducted a family study to evaluate whether a phenotypic expression could be associated to these nucleotide changes. Because of the limited numbers of cases for each mutation, the significance of these nucleotide substitutions has still not been fully clarified, and this raises a number of questions that need to be answered when carrying out appropriate genetic counseling for couples presumed to be at risk.

\section{Introduction}

Molecular defects that give rise to $\beta$-thalassemias are mainly due to point mutations affecting both regulating and coding regions of the $\beta$-globin gene. These mutations may cause absence or reduction of $\beta$-globin chain synthesis resulting in more or less pronounced imbal- ance of the normal $\beta / \alpha$ ratio. ${ }^{1,2}$ Depending on where the mutation is located, it is possible to some extent to correlate the phenotypic expression of the genetic defect. Mutations in the promoter region may cause defects in transcription, while mutations within introns (invariant dinucleotides, consensus sequences) or in the cleavage and polyadenylation site may give rise to defects in maturation of pre-mRNA. ${ }^{3}$ Mutations in the CAP site area or within exons often produce defects in translation of mRNA while defects in the third exon are generally more severe, producing hemolysis also in the carrier. ${ }^{4,5}$

In the ten years from 2003 to 2012 , during the screening program conducted at the Laboratory for Molecular Prenatal Diagnosis of Hemoglobinopathies at the Villa Sofia-Cervello Hospital in Palermo, Italy, we have analyzed no less then 34,000 individuals using standard basic hematologic and biochemical methods. In this cohort, we have found 8875 (26.1\%) $\beta$ thalassemia carriers, 1330 (3.9\%) hemoglobin variants in which the mutation was characterized by molecular analysis, and a number of suspected cases (4235) (12.4\%) with borderline $\mathrm{HbA}_{2} \%$ and/or suspected hematologic parameters that we have selected for direct DNA sequencing. In this cohort, we have found 535 cases having nucleotide anomalies not (or rarely) reported in the literature the phenotypic expression of which still has to be fully clarified. ${ }^{67}$ In this study, we have attempted to improve the phenotypic interpretation of these $\beta$ gene sequence anomalies in order to be able to formulate a phenotype/genotype correlation and to provide appropriate genetic counseling for couples presumed to be at risk.

\section{Materials and Methods}

Our laboratory carries out regional screening programs to identify healthy carriers of thalassemia and abnormal hemoglobins associated with severe pathologies, such as $\beta$-thalassemia major and sickle cell disease.$^{8,9}$ The diagnostic process is divided into two phases.

\section{Phase I: basic}

i) Standard hematologic tests: complete blood count (CBC) (AcT diff.; Beckman Coulter, Fullerton, CA, USA) and ferritin value (Kryptor Compact; Brahms Company, Hennigsdorf, Germany);

ii) separation and measurement of normal and abnormal $\mathrm{Hb}$ fraction; estimation of $\mathrm{HbA}_{2}$ and $\mathrm{HbF}$ values by high performance liquid chromatography (HPLC) (Variant II ${ }^{\mathrm{TM}}$, BioRad Laboratories, Hercules, CA, USA); ${ }^{10}$

iii) putative detection of $\mathrm{Hb}$ variants by HPLC.
Correspondence: Giambona Antonino, via G.L. Bernini 135, 90145 Palermo, Italy.

Tel. +39.091.6802770 - Fax: +39.091.6885619.

E-mail: a.giambona@villasofia.it

Key words: thalassemia, nucleotide substitutions, genetic counseling.

Acknowledgments: the authors are grateful to the Piera and Franco Cutino Foundation 0.N.L.U.S.

Contributions: MV, AG, study concept and design, writing the manuscript, and critical manuscript revision; $\mathrm{MC}$, data acquisition and writing the manuscript; FC, PLG, data acquisition and critical manuscript revision; FL, data analysis and interpretation, and critical manuscript revision; $\mathrm{CP}$, data analysis and interpretation, and writing the manuscript. All authors approved the final version to be published.

Conflict of interests: the authors declare no potential conflict of interests.

Received for publication: 17 July 2012.

Revision received: 25 September 2012

Accepted for publication: 26 September 2012.

This work is licensed under a Creative Commons Attribution 3.0 License (by-nc 3.0).

(C) Copyright M. Vinciguerra et al., 2012

Licensee PAGEPress, Italy

Thalassemia Reports 2012; 2:e4

doi:10.4081/thal.2012.e4

\section{Phase II: molecular}

Up to 2003 , in our laboratory we used the classical molecular techniques: reverse dot blot, amplification refractory mutation system, single nucleotide polymorphism and restriction enzymes. DNA sequencing was only occasionally used because the classical methods covered the most common known mutations in our region. ${ }^{11-13}$ However, due to changes in the ethnic profile of our population and the failure to identify rare mutations, particularly in phenotypes with border-line values of $\mathrm{HbA}_{2}$ in presence or absence of mild microcytosis, ${ }^{14-16}$ we have adopted direct DNA sequencing. For the last decade, this has been our standard molecular method. ${ }^{17}$

DNA is obtained from peripheral blood leukocytes using the phenol-chloroform method. ${ }^{18}$ The $\beta$-globin gene is amplified and sequenced with specific primers (Table 1$)^{19}$ and analyzed from -130 nucleotides to the Cap site to +150 nucleotides 3 ' to the Poly A site. DNA sequencing reactions are performed on amplified polymerase chain reaction (PCR) fragments using the same primers as for PCR and internal primers (Table 1). Exo-Sap reaction (United States Biochemical Corp., Cleveland, OH, USA) and Dye terminator kit 
(Applied Biosystems, Foster City, CA, USA) are used; the reactions are run on an $\mathrm{ABI}$ PRISM $^{\text {TM }} 3130 \mathrm{xl}$ automated sequencer (Applied Biosystems).

\section{Results}

Among the 535 unclear cases having nucleotide anomalies selected during the ten years of screening programs, we have identified 27 different nucleotide changes of the $\beta$ globin gene. Most of these are either not reported in the literature or are mentioned in rare cases without a clear understanding of the exact phenotypic expression. ${ }^{20}$ The nucleotide substitutions are distributed as follows (Figures 1 and 2, Table 2):

- three at 5 ' of $\beta$-globin gene;

- two at CAP site;

- one in the first intron;

- two in the second exon;

- nine in the second intron;

- two in the third exon;

- eight at 3 ' of $\beta$-globin gene.

Figure 3 shows the distribution of the nucleotide changes with the $\mathrm{CAP}+1707 \mathrm{G}>\mathrm{C}$ and IVS II nt $478 \mathrm{C}>\mathrm{A}$ occurring at the highest frequency. In order to verify whether these changes are active mutations or silent polymorphisms, we have carefully evaluated CBC and hemoglobin analysis for each of them (Table 3) and, wherever possible, we have conducted a family study (substitutions marked with ${ }^{*}$ ) to evaluate whether the phenotypic expression is actually the consequence of the identified change or is associated with another conditions. Table 3 shows that all reported phenotypes have borderline values of $\mathrm{HbA}_{2}$ with mild or absent microcytosis. For obvious reasons, we only show one sequencing example. We have selected the nucleotide substitution $\mathrm{CAP}+1570(\mathrm{~T}>\mathrm{C})$ (Figure 4) that was previously reported as a $\beta^{+}$thalassemia mutation ${ }^{21}$ and later as a plain polymorphism. ${ }^{22}$ Also in our cases, this substitution was associated with a normal phenotype. Three substitutions were found in compound heterozygosity in trans with a $\beta$-thal mutation that should then account for the more marked microcytosis (Table 3). Of all nucleotide substitutions, only CAP 1707 (G>C) and IVS II nt $478(\mathrm{C}>\mathrm{A})$ have been found also in homozygous state and with still normal phenotypes, confirming these mutations as plain polymorphisms (Table 2 and Figure 3). Similarly, the IVS II nt 478 (C>A) mutation found in a lower number of cases, alone or associated with $\mathrm{Hb}$ GCopenhagen (Codon 47 GAT>AAT), was constantly showing a normal phenotype and could be defined as a silent polymorphism; it was also revealed that the $\beta$-variant $\mathrm{Hb}$ GCopenhagen (Codon 47 GAT>AAT) is always
Table 1. Primers used for DNA sequencing of the $\beta$-globin gene with sequences and positions in the $\beta$-globin gene cluster.

\begin{tabular}{lll}
\hline Primers & Sequences $\left(5^{\prime} \rightarrow 3^{\prime}\right)$ & Positions* \\
A & AGAGATATATCTTAGAGGGAGGG & $61933-61955$ \\
B & AGTCAGTGCCTATCAGAAACCCAA & $62376-62351$ \\
\hline C & CAGAGAAGACTCTTGGGTTTC & $62339-62367$ \\
D & GAAAACAATTGTTATGAACAGCA & $62814-62792$ \\
\hline E & GTTTAGAATGGGAACAGACGATTA & $62721-62746$ \\
F & GAAAGAAAGAGATTAGGGAAAGTATTA & $63204-63174$ \\
\hline G & GCACACAGACCAGCAGGTT & $63509-63491$ \\
H & GGGTTAAGGCAATAGCAAT & $63276-63294$ \\
\hline I & GGCATAGGCATCAGGGCTGTT & $63931-63911$ \\
\hline
\end{tabular}

*Positions are given according to the Gene Bank U01317.1

Table 2. Number of reported cases for each nucleotide changes in the $\beta$-globin gene identified in our laboratory from 2003 to 2012.

\begin{tabular}{|c|c|c|c|}
\hline Location in $\beta$-globin gene & $\begin{array}{l}\text { Nucleotide } \\
\text { changes }\end{array}$ & $\begin{array}{l}\text { Phenotypic } \\
\text { effect }\end{array}$ & $\begin{array}{l}\text { No. reported } \\
\text { cases }\end{array}$ \\
\hline $5^{\prime} \beta$-globin gene & $\begin{array}{l}-223 \mathrm{~T}>\mathrm{C} \\
-138 \mathrm{C}>\mathrm{G} \\
-20 \mathrm{G}>\mathrm{A}\end{array}$ & $\begin{array}{l}\text { Plain polymorphism } \\
\text { Presumable polymorphism } \\
\text { Presumable polymorphism }\end{array}$ & $\begin{array}{l}6 \\
1 \\
1\end{array}$ \\
\hline CAP site & $\begin{array}{l}\text { CAP } 16 \text { A }>\text { G } \\
\text { CAP } 17 \text { C }>\text { G }\end{array}$ & $\begin{array}{l}\text { Presumable polymorphism } \\
\text { Presumable polymorphism }\end{array}$ & $\begin{array}{l}2 \\
1\end{array}$ \\
\hline IVS I & IVS I nt $36 \mathrm{C}>\mathrm{A}$ & Presumable polymorphism & 1 \\
\hline Exon 2 & $\begin{aligned} \text { Codon } 59 \mathrm{AAG} & >\mathrm{AAA} \\
\text { Codon } 100 \mathrm{CCT} & >\mathrm{CC} \underline{\mathrm{C}}\end{aligned}$ & $\begin{array}{l}\text { Presumable polymorphism } \\
\text { Presumable polymorphism }\end{array}$ & $\begin{array}{l}1 \\
3\end{array}$ \\
\hline IVS II & $\begin{array}{l}\text { IVS II nt } 143 \mathrm{G}>\mathrm{A} \\
\text { IVS II nt } 257 \mathrm{~T}>\mathrm{G} \\
\text { IVS II nt } 350 \mathrm{G}>\mathrm{A} \\
\text { IVS II nt } 377 \mathrm{C}>\mathrm{T} \\
\text { IVS II nt } 380 \mathrm{~T}>\mathrm{C} \\
\text { IVS II nt } 478 \mathrm{C}>\mathrm{A} \\
\text { IVS II nt } 527 \mathrm{~A}>\mathrm{G} \\
\text { IVS II nt } 713 \mathrm{G}>\mathrm{A} \\
\text { IVS II nt } 726 \mathrm{~A}>\mathrm{G}\end{array}$ & $\begin{array}{l}\text { Presumable polymorphism } \\
\text { Presumable polymorphism } \\
\text { Plain polymorphism } \\
\text { Presumable polymorphism } \\
\text { Plain polymorphism } \\
\text { Plain polymorphism } \\
\text { Presumable polymorphism } \\
\text { Presumable polymorphism } \\
\text { Presumable polymorphism }\end{array}$ & $\begin{array}{c}1 \\
1 \\
6 \\
1 \\
5 \\
56 \\
1 \\
1 \\
2\end{array}$ \\
\hline Exon 3 & $\begin{array}{l}\text { Codon } 133 \mathrm{GT} \underline{\mathrm{G}}>\mathrm{GTC} \underline{\mathrm{C}} \\
\text { Codon } 143 \mathrm{CA} \underline{\mathrm{C}}>\mathrm{CA} \underline{\underline{T}}\end{array}$ & $\begin{array}{c}\text { Plain polymorphism } \\
\text { Presumable polymorphism }\end{array}$ & $\begin{array}{c}12 \\
1\end{array}$ \\
\hline 3' $\beta$-globin gene & $\begin{aligned} \mathrm{CAP}+1510 \mathrm{C}>\mathrm{T} \\
\mathrm{CAP}+1570 \mathrm{~T}>\mathrm{C} \\
\mathrm{CAP}+1642 \mathrm{~A}>\mathrm{G} \\
\mathrm{CAP}+1643 \mathrm{~A}>\mathrm{T} \\
\mathrm{CAP}+1656 \mathrm{G}>\mathrm{A} \\
\mathrm{CAP}+1705 \mathrm{~T}>\mathrm{C} \\
\mathrm{CAP}+1707 \mathrm{G}>\mathrm{C} \\
\mathrm{CAP}+1770 \mathrm{~T}>\mathrm{C} \\
\text { Total }\end{aligned}$ & $\begin{array}{c}\text { Presumable polymorphism } \\
\text { Presumable polymorphism } \\
\text { Presumable polymorphism } \\
\text { Presumable polymorphism } \\
\text { Presumable polymorphism } \\
\text { Plain polymorphism } \\
\text { Plain polymorphism } \\
\text { Plain polymorphism }\end{array}$ & $\begin{array}{c}4 \\
20 \\
3 \\
3 \\
10 \\
5 \\
378 \\
6 \\
532\end{array}$ \\
\hline
\end{tabular}

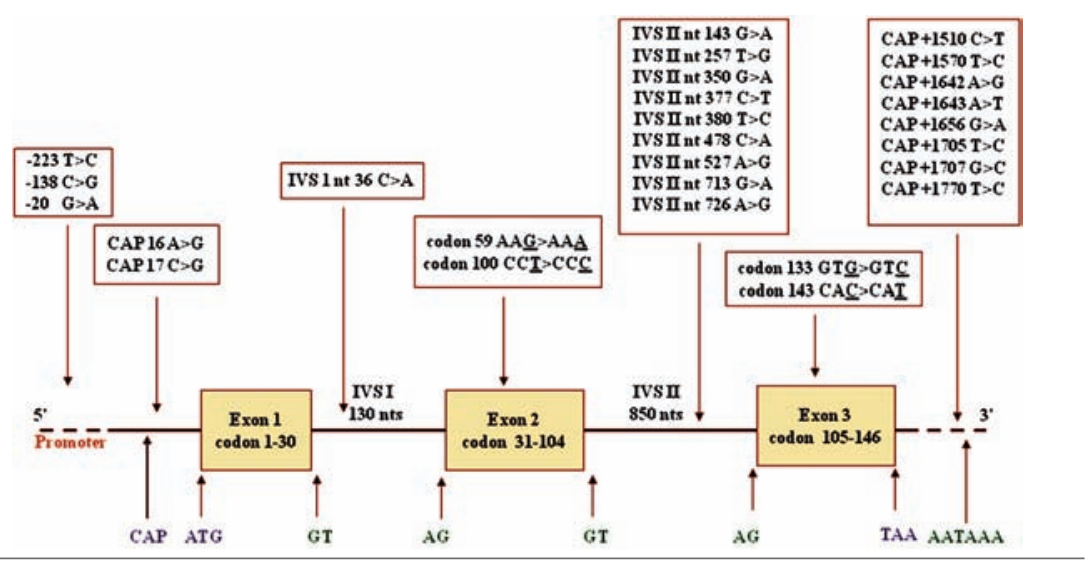

Figure 1. Location of the 27 nucleotide changes identified within the $\beta$-globin gene. 
associated with this ambiguity, but not vice versa. Because of the limited numbers of cases for each mutation, it is difficult to predict whether any of those mutations could be found associated with a thalassemic effect (Table 3 ). Among all 4235 suspected cases having phenotypes with borderline values of $\mathrm{HbA}_{2}$ with mild or absent microcytosis, 3700 resulted normal without thalassemia mutation and without polymorphisms. This fact probably indicates the existence of genetic determinants not yet molecularly defined or the presence of other factors (drugs, other pathologies such as hyperthyroidism) causing the mild increase in $\mathrm{HbA}_{2}$ level or also may be due to an outlier value of the normal $\mathrm{HbA}_{2}$ distribution in Sicilian non-carrier subjects.
In all cases reported in Table 3 , genetic counseling has been carried out in order to explain the nature of the observed molecular nucleotide substitution and the possible risks for the couple in case of a pregnancy.

\section{Discussion}

Basic diagnostics of $\beta$-thalassemia carriers is simple when separation and measurement of the $\mathrm{Hb}$ fractions show $\mathrm{HbA}_{2}$ higher then $4 \%$, eventually some $\mathrm{HbF}^{23}$ and this in association with specific hypochromic microcytic parameters, some anemia eventually compensated by an elevated RBC count, and a classic erythromorphology. However, quite a few cases may present with borderline levels of $\mathrm{HbA}_{2}$, no $\mathrm{HbF}$, and indecisive $\mathrm{CBC}$ parameters. Then $\mathrm{HbA}_{2}$ determination can be a source of errors ${ }^{24}$ and quite a few inter-laboratory variations ${ }^{25}$ and technical pitfalls ${ }^{26}$ may cause misdiagnosis when $\mathrm{HbA}_{2}$ is considered to be a decisive cut off parameter. These gray area cases must be very carefully examined, especially when they are part of a risk assessment with a partner carrier of a plain $\beta$ thalassemia mutation. Then direct sequencing should always be performed to exclude mild or silent $\beta$-thalassemia mutations that could, however, cause intermediate if not severe conditions in combined heterozygosis. Furthermore, mutations can be found that are either unknown or undefined for their phenotype and risk, like those pre-

Table 3. Nucleotide substitutions identified in heterozygous state and related phenotypes, and cases of compound heterozygosity with other alterations in $\beta$-gene, except for IVS II nt $478(C>A)$ and CAP $+1707(G>C)$ that were found in associations with many different globin gene changes without further effect.

\begin{tabular}{|c|c|c|c|c|c|c|c|c|c|c|c|c|}
\hline Ambiguity & $\begin{array}{c}\text { RBC } \\
\left(10^{6} / \mathrm{L}\right)\end{array}$ & $\begin{array}{l}\mathrm{Hb} \\
(\mathrm{g} / \mathrm{dL})\end{array}$ & $\begin{array}{l}\text { Het } \\
(\%)\end{array}$ & $\begin{array}{l}\text { MCV } \\
\text { (fL) }\end{array}$ & $\begin{array}{c}\mathrm{MCH} \\
(\mathrm{pg})\end{array}$ & $\begin{array}{l}\text { MCHC } \\
\text { (g/dL) }\end{array}$ & $\begin{array}{l}\text { RDW } \\
(\%)\end{array}$ & $\begin{array}{l}\mathrm{HbA}_{2} \\
(\%)\end{array}$ & $\begin{array}{l}\text { HbF } \\
(\%)\end{array}$ & $\begin{array}{l}\text { Ferritin } \\
(\mathrm{ng} / \mathrm{mL})\end{array}$ & $\begin{array}{l}\text { Hb variants } \\
\text { (\%) }\end{array}$ & $\begin{array}{l}\text { Other } \\
\text { mutations in } \\
\beta \text {-globin gene }\end{array}$ \\
\hline$-223 \mathrm{~T}>\mathrm{C}$ & 4.4 & 12.8 & 38.2 & 84 & 27.5 & 34.2 & 13.7 & 3.1 & 0.3 & 67 & l & 1 \\
\hline$-138 \mathrm{G}>\mathrm{C}$ & 2.75 & 6.9 & 25 & 91 & 25.3 & 27.8 & 22.4 & 5 & 2.5 & 26 & 1 & Codon 39/NEG \\
\hline$-20 \mathrm{G}>\mathrm{A}$ & 5.09 & 15.2 & 45.2 & 89 & 29.8 & 33.5 & 12.4 & 4 & 0.9 & 46 & $\mathrm{Hb} \mathrm{S}=38.9 \%$ & 1 \\
\hline CAP 16 A $>G^{*}$ & 4.83 & 12.7 & 39 & 80.7 & 26.3 & 32.6 & 14.7 & 2.8 & 0.3 & 28 & 1 & I \\
\hline CAP 17 C>G & 5.01 & 12.8 & 37.2 & 85 & 27.1 & 34.2 & 13.5 & 3.1 & 0.4 & 58 & I & I \\
\hline IVS I nt $36 \mathrm{C}>\mathrm{A}$ & 3.59 & 11.3 & 32.5 & 91 & 31.3 & 34.6 & 12.7 & 3.3 & 0.3 & 39 & l & I \\
\hline Codon 59 AAG>AAA & 5.31 & 13.3 & 38.2 & 71.9 & 25 & 31.2 & 14.5 & 2.7 & 0.3 & 29 & I & I \\
\hline Codon 100 CCT>CCC & 4.87 & 15.8 & 45.4 & 93 & 32.4 & 30.1 & 11.6 & 3 & 0.3 & 43 & l & l \\
\hline IVS II nt $143 \mathrm{G}>\mathrm{A}$ & 4.62 & 11.5 & 34.9 & 75 & 24.8 & 32.9 & 16.4 & 2.5 & 0.1 & 53 & l & l \\
\hline IVS II nt $257 \mathrm{~T}>\mathrm{G}$ & 4.51 & 8.5 & 38.2 & 63 & 25.1 & 32.5 & 13.7 & 4.9 & 10 & 16 & l & $-101 / \operatorname{codon} 39$ \\
\hline IVS II nt $350 \mathrm{G}>\mathrm{A}$ & 4.36 & 12.7 & 36.8 & 84 & 29.1 & 34.4 & 14.2 & 3 & 0.5 & 21 & I & / \\
\hline IVS II nt $377 \mathrm{C}>\mathrm{T}$ & 4.53 & 13.1 & 38.3 & 85 & 29 & 34.3 & 12.2 & 3.4 & 0.4 & 49 & I & l \\
\hline IVS II nt $380 \mathrm{~T}>\mathrm{C}$ & 3.96 & 11.8 & 34.2 & 86.3 & 29.3 & 34.5 & 15.1 & 3.3 & 0 & 19 & / & / \\
\hline $\begin{array}{l}\text { IVS II nt } 478 \mathrm{C}>\mathrm{A}^{*} \\
\text { (also in homozygous state) }\end{array}$ & $\begin{array}{l}4.32 \\
4.01\end{array}$ & $\begin{array}{l}12.8 \\
12.3\end{array}$ & $\begin{array}{l}38.0 \\
38.2\end{array}$ & $\begin{array}{l}87.9 \\
95.4\end{array}$ & $\begin{array}{l}29.5 \\
30.8\end{array}$ & $\begin{array}{l}33.6 \\
33.2\end{array}$ & $\begin{array}{l}13.1 \\
13.1\end{array}$ & $\begin{array}{c}3.2 \\
48.1\end{array}$ & $\begin{array}{l}0.2 \\
1.1\end{array}$ & $\begin{array}{l}51 \\
67\end{array}$ & $\begin{array}{c}\text { / } \\
\text { Hb G-Copenhagen }\end{array}$ & $\begin{array}{l}1 \\
1\end{array}$ \\
\hline IVS II nt $527 \mathrm{~A}>\mathrm{G}$ & 3.69 & 11.1 & 32.6 & 88.1 & 30.1 & 34.1 & 12.7 & 3.3 & 0 & 71 & / & / \\
\hline IVS II nt $713 \mathrm{G}>\mathrm{A}$ & 4.77 & 13.3 & 38.5 & 80.7 & 27.9 & 34.5 & 13.9 & 3.3 & 0.9 & 23 & l & l \\
\hline IVS II nt $726 \mathrm{~A}>\mathrm{G}$ & 4.27 & 11.7 & 34.7 & 81 & 28.1 & 31.3 & 13.4 & 2.9 & 1.6 & 35 & I & I \\
\hline Codon 133 GTG>GTC* & 4.71 & 13.1 & 38.5 & 82 & 27.9 & 34 & 12.8 & 3.2 & 1.3 & 48 & / & l \\
\hline Codon 143 CAC>CAT & 5.4 & 10.9 & 35.5 & 66 & 20.2 & 30.7 & 19.2 & 2.7 & 0.8 & 14 & I & I \\
\hline $\mathrm{CAP}+1510 \mathrm{C}>\mathrm{T}$ & 4.57 & 13.2 & 39 & 85 & 28.8 & 33.8 & 13 & 3.4 & 0 & 27 & l & l \\
\hline $\mathrm{CAP}+1570 \mathrm{~T}>\mathrm{C}^{*}$ & 4.20 & 12.8 & 37.8 & 89.1 & 30.2 & 33.9 & 13 & 3.3 & 0.9 & 26 & l & l \\
\hline CAP $1642 \mathrm{~A}>\mathrm{G}$ & 4.44 & 13.8 & 40.7 & 92 & 31 & 33.8 & 12.9 & 2.9 & 0.3 & 33 & l & l \\
\hline CAP $1643 \mathrm{~A}>\mathrm{T}$ & 4.07 & 12.3 & 36.2 & 89 & 30.3 & 34.1 & 13.6 & 2.8 & 0.4 & 65 & l & 1 \\
\hline $\mathrm{CAP}+1656 \mathrm{G}>\mathrm{A}^{*}$ & $\begin{array}{l}4.26 \\
6.02\end{array}$ & $\begin{array}{l}12.3 \\
13.2\end{array}$ & $\begin{array}{l}35.4 \\
40.7\end{array}$ & $\begin{array}{l}83.0 \\
67.8\end{array}$ & $\begin{array}{l}28.9 \\
22.0\end{array}$ & $\begin{array}{l}34.8 \\
32.5 \\
\end{array}$ & $\begin{array}{l}12.7 \\
16.5 \\
\end{array}$ & $\begin{array}{l}3.3 \\
8.9\end{array}$ & $\begin{array}{c}0 \\
4.0\end{array}$ & $\begin{array}{l}52 \\
19 \\
\end{array}$ & $\begin{array}{l}1 \\
1\end{array}$ & del 1393 \\
\hline $\mathrm{CAP}+1705 \mathrm{~T}>\mathrm{C}$ & 5.23 & 16.5 & 48.3 & 92 & 31.6 & 34.3 & 13 & 3.2 & 0.2 & 47 & I & I \\
\hline $\begin{array}{l}\mathrm{CAP}+1707 \mathrm{G}>\mathrm{C}^{*} \\
\text { (also in homozygous state) }\end{array}$ & 5.01 & 13.5 & 40.3 & 86.7 & 29.5 & 35.3 & 12.6 & 3.1 & 0.3 & 55 & l & l \\
\hline $\mathrm{CAP}+1770 \mathrm{~T}>\mathrm{C}$ & 5.23 & 14.6 & 42.6 & 81.1 & 27.8 & 34.2 & 13.3 & 3.1 & 0.4 & 39 & 1 & 1 \\
\hline
\end{tabular}




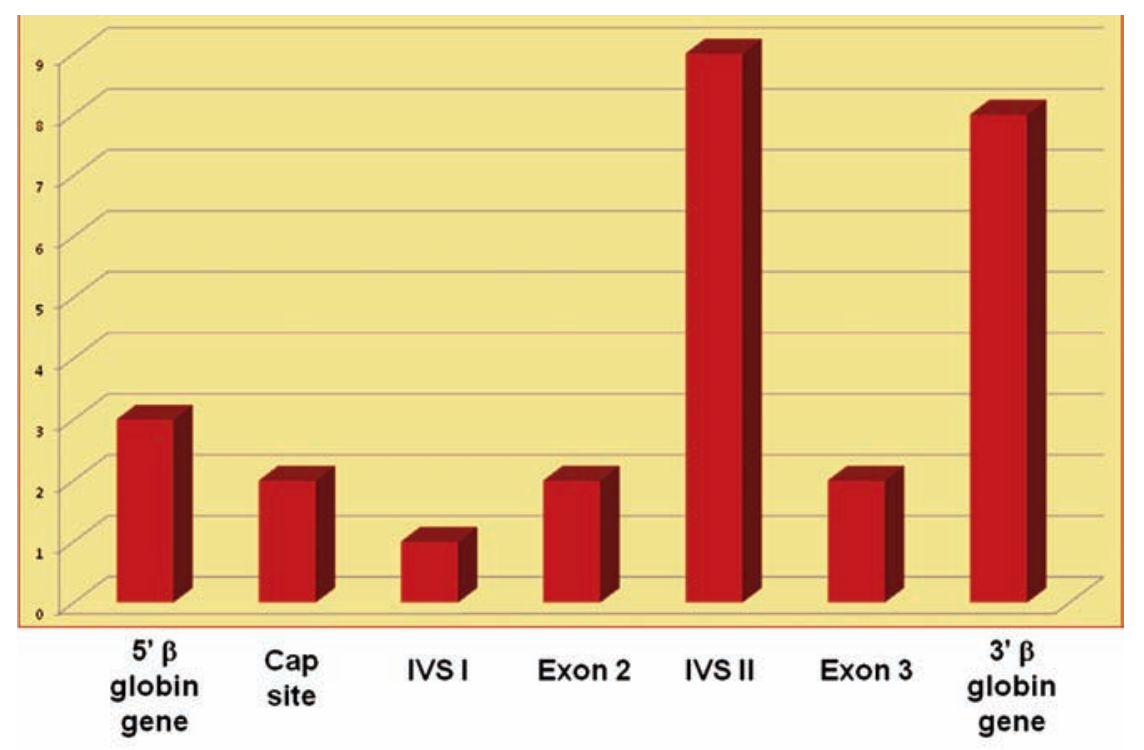

Figure 2. Frequency of the 27 nucleotide changes identified within the $\beta$-globin gene.

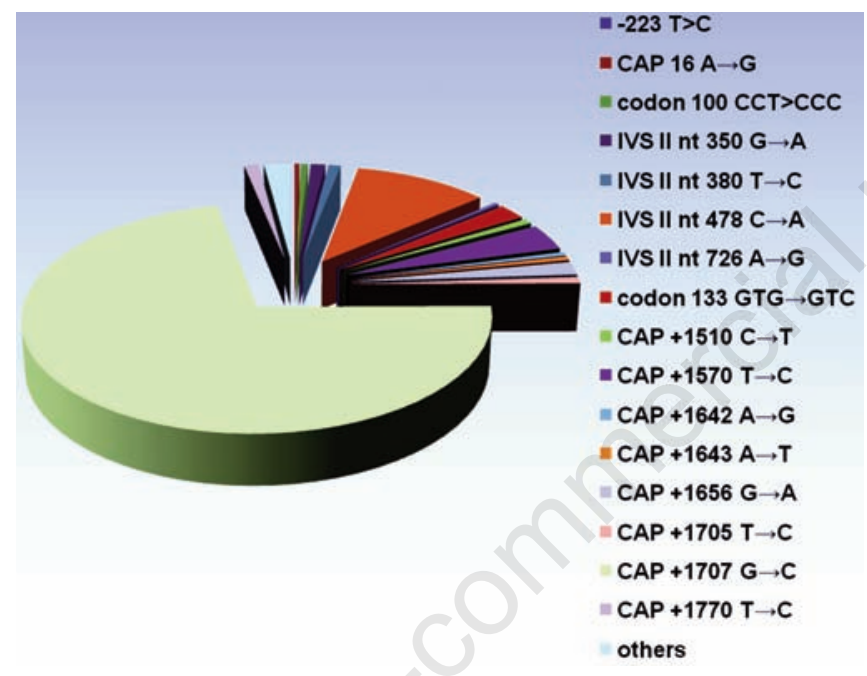

Figure 3. Distribution of the 27 identified nucleotide changes in the $\beta$-globin gene in relation to 532 reported cases.

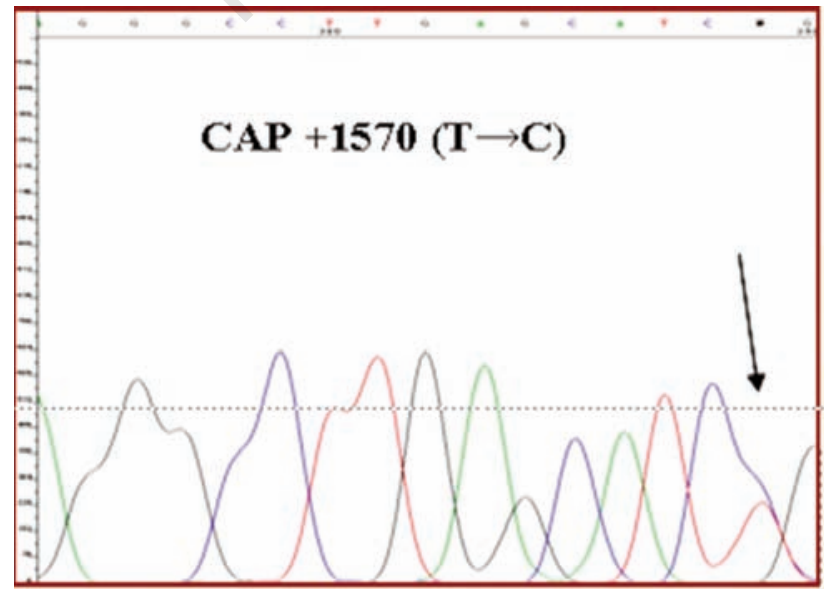

Figure 4. Partial DNA sequence of the CAP $+1570(\mathrm{~T}>\mathrm{C})$ mutation. Nucleotide substitution present in heterozygous state (arrow). sented in this study. In these cases, the tools to decide how to council patients are limited to the careful observation of the $\mathrm{CBC}$ and the study of the family. Alternatively, one may perform a globin chain synthesis using one of the rapid methods available ${ }^{27}$ or may rely on prediction programs such as ALAMUT ${ }^{28}$ or programs that can be found online such as: i) PolyPhen (http://genetics.bwh.harvard. edu /pph2/index.shtml); or ii) sorting intolerant from tolerant (SIFT) (http://sift. jcvi.org/www/ SIFT_seq_submit2.html).

In any case, a complete $\beta$ globin gene analysis must be performed first.

Over the past two decades, a wide range of available methods for DNA analysis have allowed us to identify defects in globin genes associated with hemoglobin disorders and to correlate specific mutations with phenotypic expression. During this process, uncertain mutations have too often gone unreported in the literature, which complicates the counseling procedure whenever one of these molecular changes is found.

Therefore, the authors of this paper recommend all colleagues to assess the nature of the nucleotide changes found (mutation or polymorphism) and to report them to the HbVAR database. ${ }^{29}$ Furthermore, they should, when possible, evaluate if the phenotypic expression of healthy carriers is a consequence of the identified mutation, predict the phenotype resulting from the interaction between the uncertain mutation with an allele with known $\beta$-thalassemia mutations or $\beta$-variants, and carry out a family study, over several generation if possible.

These recommendations are guided by the need to formulate a clinical report or an appropriate genetic counseling for couples at risk.

In conclusion, genetic counseling is an essential and valuable tool for prospective primary prevention and, for this reason, it must be conducted by competent personnel and with reliable data. This is even more important in the case of new or rare undefined mutations that have not been well described in literature, because it is difficult to determine the actual phenotypic expression and the possible interactions with known molecular defects on the basis of a small number of identified cases.

For this reason, in our laboratories we will continue to evaluate the significance of any new mutation characterized at the molecular and phenotypic level.

\section{References}

1. Rund D. Rachmilewitz E. Beta-thalassemia. N Engl J Med 2005;353:1135-46.

2. Kazazian HH Jr. Gene structure and the nature of mutation. Mead Johnson Symp 
Perinat Dev Med 1983;22:3-11.

3. Wong C, Antonarakis SE, Pobedimskaya $\mathrm{DD}$, et al. Beta-thalassemia due to two novel nucleotide substitutions in consensus acceptor splice sequences of the betaglobin gene. Blood 1989;73:914-8.

4. Cao A, Gossens M, Pirastu M. Beta thalassaemia mutations in Mediterranean populations. Br J Haematol 1989;71:309-12.

5. Flint J, Harding RM, Boyce AJ, Clegg JB. The population genetics of the haemoglobinopathies. Baillieres Clin Haemat 1998;11:1-51.

6. Orkin SH, Antonarakis SE, Kazazian HH Jr. Polymorphism and molecular pathology of the human beta-globin gene. Prog Hematol 1983;13:49-73.

7. Orkin SH, Kazazian HH Jr. The mutation and polymorphism of the human beta-globin gene and its surrounding DNA. Annu Rev Genet 1984;18:131-71.

8. Kazazian HH, Boehm CD. Molecular basis and prenatal diagnosis of beta thalassemia. Blood 1988;72:1107-16.

9. Moatter T, Kausar T, Aban M, et al. Prenatal screening for $\beta$-thalassemia major reveals new and rare mutations in the Pakistani population. Int J Hematol 2012;95:394-8.

10. Mosca A, Paleari R, Galanello R, et al. New analytical tools and epidemiological data for the identification of $\mathrm{HbA} 2$ borderline subjects in the screening for beta-thalassemia. Bioelectrochemistry 2008;73: 137-40.

11. Giambona A, Lo Gioco P, Marino M, et al. The great heterogeneity of thalassemia molecular defects in Sicily. Hum Genet 1995;95:526-30.

12. Giambona A, Vinciguerra M, Cannata M, et al. The genetic heterogeneity of $\beta$-globin gene defects in Sicily reflects the historic population migrations of the island. Blood Cells Mol Dis 2011;46:282-7.

13. Di Marzo R, Dowling CE, Wong $\mathrm{C}$, et al. The spectrum of $\beta$-thalassemia mutations in Sicily. Br J Haematol 1988;69:393-7.

14. Giambona A, Passarello C, Renda D, Maggio A. The significance of the hemoglobin A2 value in screening for hemoglobinopathies. Clin Biochem 2009;42:178696.

15. Giambona A, Passarello C, Vinciguerra M, et al. Significance of borderline hemoglobin $\mathrm{A} 2$ values in an Italian population with a high prevalence of beta-thalassemia. Haematologica 2008;93:1380-4.

16. Schilirò G, Mirabile E, Testa R, et al. Presence of Hemoglobinopathies in Sicily. Am J Med Genet 1997;69:200-6.

17. Georgel AF, Méreau C, Willekens $\mathrm{C}$, et al. Identification of a new mutation on the beta-globin gene: codons 8/9 (+AGAA); GAG.AAG.TCT(Glu-Lys-Ser)>GAG. AAAGAAG. in a patient from the north of France with a phenotype of beta-thalassemia minor. Hemoglobin 2010;34:38993.

18. Köchl S, Niederstätter H, Parson W. DNA extraction and quantitation of forensic samples using the phenol-chloroform method and real-time PCR. Methods Mol Biol 2005; 297:13-30.

19. Giambona A, Vinciguerra M, Cassarà F, et al. Hb Marineo [ $\beta 70($ E14)Ala $\rightarrow$ Val]: a silent hemoglobin variant with a mutation within the heme pocket. Hemoglobin 2006;30:139-48.

20. Laboratories of Computer Science \& Engineering and Biochemistry \&
Molecular Biology. Pennsylvania State University. The globin Gene server. Available from: http://globin.cse.psu.edu

21. Cai SP, Eng B, Francombe WH, et al. Two novel $\beta$-thalassemia mutations in the 5 ' and 3' noncoding regions of the $\beta$-globin gene. Blood 1992;79:1342.

22. Eng B, Waye JS, Chui DHK. The $\mathrm{C} \longrightarrow \mathrm{T}$ substitution at nucleotide +1570 of the $\beta$ globin gene is a polymorphism. Blood 1992;80:1365.

23. Stephens AD, Angastiniotis M, Baysal E, et al. International Council for The Standardisation of Haematology (ICSH). Int J Lab Hematol 2012;34:14-20.

24. Stephens AD, Angastiniotis M, Baysal E, et al. International Council for the Standardisation of Haematology (ICSH). Int J Lab Hematol 2012;34:1-13.

25. Paleari R, Gulbis B, Cotton F, Mosca A. Interlaboratory comparison of current high-performance methods for $\mathrm{HbA}(2)$. Int J Lab Hematol 2012;34:362-8.

26. Giordano PC. Measurement of HbA2. Int J Lab Hematol 2012;34:335.

27. Giordano PC, Van Delft P, Batelaan D, et al. Haemoglobinopathy analyses in the Netherlands: a report of an in vitro globin chain biosynthesis survey using a rapid. modified method. Clin Lab Haematol 1999;21:247-56.

28. Houdayer C. In silico prediction of spliceaffecting nucleotide variants. Methods Mol Biol 2011;760:269-81.

29. Giardine B, van Baal S, Kaimakis P, et al. HbVar database of human hemoglobin variants and thalassemia mutations: 2007 update. Hum Mutat 2007;28:206. 